\title{
Strategic decisions in transport: a case study for a naval base selection in Brazil
}

\author{
Amaury Caruzzo ${ }^{1}$, Priscila Renata Barros Cardoso², Hélcio Vieira Junior ${ }^{3}$ e Mischel Carmen Neyra Belderrain ${ }^{4}$
}

\begin{abstract}
A decision on a military strategic environment, such as the selection of a new naval base, is a complex process and involves various criteria. In this context, few studies are available on the problems of military-naval transport decisions. Therefore, the aim of this paper is to present a maritime transport case study using a multi-methodology framework in a process of strategic decision making in logistics. Through a review of the literature, normative documents from the Brazilian armed forces, and interviews with military officers, criteria and preferences were identified and a hierarchical structure was constructed for a case study in the Brazilian Navy-the location of the second Fleet Headquarters. The results indicated that São Marcos Bay, in Maranhão State, was the best location among the alternatives. The multi-criteria approach was shown to be a valuable tool in assisting the decision making process and to understand the trade-offs between strategic and operational criteria in a transport decision.

Keywords: port selection; maritime transport; decision analysis; MCDA; Brazilian navy.
\end{abstract}

Resumo: Decisões em um ambiente estratégico-militar, como a seleção de uma nova base naval, são processos complexos e que envolvem diversos critérios. Neste contexto, poucos estudos estão disponíveis sobre o problema de tomada decisão em transporte militar-naval. Portanto, o objetivo deste artigo é apresentar um estudo de caso utilizando um método multicritério em um processo de tomada de decisão estratégico-militar em logística. Por meio da revisão da literatura, de documentos normativos das Forças Armadas e de entrevistas com militares, foram identificados os critérios, as preferências e foi construída a estrutura hierárquica para um caso real da Marinha do Brasil, na localização da segunda sede da Esquadra na costa Norte e Nordeste brasileira. O resultado indicou que a Baía de São Marcos, no Maranhão, é a melhor localização entre as alternativas consideradas. O método multicritério demostrou ser uma ferramenta válida para auxiliar no processo decisório e para entender as compensações entre os critérios estratégicos e operacionais em uma decisão de transporte.

Palavras-chave: seleção de portos; transporte marítimo; análise de decisão; MCDA; marinha do brasil.

\section{INTRODUCTION}

The process of decision making in logistic systems is important for organizations. In these cases, the analysis can be a complex procedure that involves many stakeholders and different interpretations of the decision (Belton and Stewart, 2002; Goodwin and Wright, 2004). Applied to the military transport or defense sector, the choice in logistics aspects has impact and in many situations, can compromise the defense strategy of a country, such as selecting a site for a new military base (Brasil, 2007b; Paloyo et al., 2010; USA, 2010; Kerr et al., 2014).

Adding to the complexity of decision making in a strategic transport, the current stage of economic growth in Brazil has been demanding an ever greater expansion of its infrastructure throughout the country. Consequently, the Brazilian Armed Forces also have the need to expand its

\footnotetext{
Amaury Caruzzo, Instituto Tecnológico de Aeronáutica (ITA) e McGill University. (amaury.caruzzo@mail.mcgill.ca)

2 Priscila Renata Barros Cardoso, Instituto Tecnológico de Aeronáutica (ITA), Grupo de Estudos de Análise de Decisão (GEAD). (prirenata@gmail.com)

${ }^{3}$ Hélcio Vieira Junior, Comando da Aeronáutica, Núcleo do Centro de Operações Espaciais Principal (NuCOPE-P). (helciovj@gmail.com)

${ }^{4}$ Mischel Carmen Neyra Belderrain, Instituto Tecnológico de Aeronáutica
(ITA), Grupo de Estudos de Análise de Decisão (GEAD). (carmen@ita.br)
}

Manuscrito recebido em 14/12/2014 e aprovado para publicação em 09/11/2015.

Este artigo é parte de TRANSPORTES v. 24, n. 1, 2016 ISSN: 2237-1346 (online). DOI: 10.14295/transportes.v24i1.874 border security and protection activities. One of the sectors most directly affected by Brazilian economic is the shipping sector and other maritime activities (Caruzzo et al., 2012). Currently, the transportation of the major part of international cargo is done by ship both in Brazil and throughout the world (Brasil, 2009; Lama and Dai; 2012; Cruz et al., 2013a). In order to protect all maritime activities off the Brazilian coast, the mobilization of naval forces and its capacity for deterrence is critical (Brasil, 2007a; 2008). As expected, the existence of a nearby naval base helps support maritime activities, to mobilize the Brazilian coastal defense forces and ensures the Nation's presence in a region where borders are not clearly visible.

The process for defining a naval base location involves multiple objectives, since it serves for both the strategic and defense purposes of the country, as well as the operational features of naval ships. To aid in this process, various decision support methods allow us to structure the problem so as to model the judgments and preferences of decision-makers. Some researchers emphasize that Multi-Criteria Decision Analysis (MCDA) methods can be structured through the values of the problem context or organizations (Figueira et al., 2005; Montibeller and Franco, 2010; Cruz et al., 2013b). In other words, the application of the MCDA method consistently assists stakeholders in identifying the criteria and the construction of the decision process.

Therefore, this article purposes are: (1) to discuss a maritime transport case study in the process of strategic military decision using a problem structuring and a MCDA method, and (2) to evaluate the key criteria for the location of a naval base on the Brazilian coast. The framework was applied in a real situation of the Brazil- 
ian Navy in the selection of the Second Brazilian Fleet Headquarters, as part of the requirements of the Brazil's National Strategy of Defense (Brasil, 2008). The contribution of this paper is to evaluate a military case study to structure a strategic decision in transport, supported by the multi-methodology, since studies on this subject and using this approach are more applied for commercial port selections.

\section{STRATEGIC DECISIONS AND MARITIME TRANSPORT}

\subsection{Brazil's National Strategy of Defense}

Over the last decade, the Brazilian government began studies with the goal of creating a strategic review of the Brazilian Armed Forces. In 2008, the Ministry of Defense of Brazil issued a document called the "National Strategy of Defense' (NSD) (Brasil, 2008). The NSD presents the principal points for long-term planning for the Brazilian Army, Navy and Air Force.

One of the guidelines set forth in the NSD is to distribute the number of Armed Forces personnel/bases throughout the States of Brazil. For the Brazilian Navy (BN), there is a strategic need to reposition its operating units so as to be more visibly present in the region of the mouth of the Amazon River as well as in the major watershed of the Amazon and the Paraguay-Paraná River. Currently the BN has a large concentration of effective elements in the Southeast region of the country, specifically in the Rio de Janeiro State. Therefore, it was proposed in the NSD, that the long term strategic objectives of the BN include the need to establish a new multiple use naval base, i.e., to service and receive all classes of vessels in the Brazilian Navy's Fleet. It was also decided that the second navy fleet headquarters should be located close to the mouth of the Amazon River (North or Northeast of Brazilian coast).

According to Hicks and Raney (2003) and Paloyo et al. (2010) in order to determine the location of a military base, the decision must not only take into consideration the strategic and tactical aspects of the military transport system. The decision must also present a well-structured social/technical/political justification in order to consider its local and global impacts on society. The complexity of selecting a new naval base is amplified when the possible use of vessels is also considered. For example, the Royal Australian Navy and U.S. Navy includes in its naval operations concepts, logistical repositioning in accordance with the requirements of international humanitarian assistance operations (USA, 2010; Kerr et al., 2014).

\subsection{Criteria for commercial port selection}

The vast majority of international trade (cargo) travels by ship. Consequently, the locations of the ports for the distribution of these goods have a strong relationship to cost and trade competitiveness. In the scientific literature, many researchers have presented studies on the problems involved in the selection of commercial ports by applying various methods and criteria (Farahani et al., 2010). However, most of these papers are focused upon existing struc- tures and do not take into consideration the need to build a port for military applications as well.

Initially Murphy and Daley (1994) highlighted some problems in the commercial port selection decision that do not take into consideration the operational aspects of cargo transportation. They also show that most studies thus far, have been focused on regional or subnational cases, utilizing a reduced range of factors, rather than examining aspects of international trade. In more recent papers Aversa et al. (2005) and Tran (2011) discussed various models, and applied Linear Programming to the factors that are important for port selection. Lirn et al. (2004) and Chang et al. (2008) raised the criteria for port locations, utilizing questionnaires distributed between companies and managers. The criteria for the selection of a civil marine structure were identified, taking into consideration the operational aspects and support for all activities related to the port. Another approach also identified in the literature is the development of the dynamic Decision Support Systems (DSS), in which the destination of a cargo ship is determined by criteria constantly being updated. For a port selection for the Netherlands shipping industry (Langen, 2004), a population cluster is defined as a geographically concentrated pool with diverse economic activities and relationships between organizations. In other DSS application (Lama and Dai, 2012), decision makers visualize a periodically updated ranking of port options for a given product market.

Magala and Sammons (2008) proposed a new approach for modelling the port selection, based on the competitiveness of ports in relation to the supply chain. This paper highlights some relevant criteria but not commonly used in other studies, for example, carbon emissions or specific service levels. Other multi-methods articles were applied to identify the best alternative port. Chou (2007) integrated fuzzy logic and the MCDA method for transporting containers. In this study, six criteria and eighteen sub-criteria were used, with the construction of a hierarchical structure for selection. Onut et al. (2011) also showed a case study of applying fuzzy logic and the Analytical Network Process in Turkey. They used twenty criteria, grouped into six categories, for the selection of HUB containers. However there are other applications that only utilize multi-criteria methods for selecting the best commercial option (Guy and Urli, 2006; Ugboma et al., 2006; Notteboom, 2011). In these papers, models were built utilizing the perceptions of the various stakeholders, such as port service providers, users and customers. There are also a number of articles on commercial port evaluation where various criteria defined by groups, stakeholders, or via regulatory document were identified (Cruz et al., 2013a; 2013b; Madeira et al., 2013). In Brazil, the only in-depth study with the aim of selecting the new naval base for the Brazilian fleet was done by of the Federal University of Pará (Brasil, 2010). In this technical report only three criteria had been proposed.

In this literature review related to port infrastructure, a total of thirty-four different sub-criteria, divided into seven main categories of criteria were identified. So it is the first identification of potential operational criteria for the selection of the naval base and that was evaluated by the Brazilian Navy's decision makers, as shown below. The Table A1 of Appendix displays a summary with main criteria identified in this literature review. 


\subsection{Multi-Criteria Decision Analysis for Strategic Decision Making}

Multi-Criteria Decision Analysis (MCDA) is an approach for comparing a set of alternatives with respect to multiple objectives (Figueira et al., 2005; Montibeller and Franco, 2010). For this, it defines a set of criteria $\mathrm{C}=\left\{\mathrm{c}_{1}, \ldots, \mathrm{c}_{\mathrm{m}}\right\}$ the decision process to select a finite set of viable alternatives $A=\left\{a_{1}, \ldots, a_{k}\right\}$. When each alternative necessarily leads to a specific outcome in the choice (without uncertainty), a suitable multi-criteria approach is through the Multi-Attribute Value Theory (MAVT) (Comes et al., 2011). On the other hand, the Multi-Attribute Utility Theory is more appropriate to conditions of uncertainty in which each alternative leads to an outcome of probability distribution (Durbach and Stewart, 2012).

As discussed by Keeney and Raiffa (1993) and Figueira et al. (2005), in MAVT the values of multiple criteria can be aggregated into a single value, allowing an overall evaluation of alternatives. In addition to MAVT facilitating the understanding of theory for decision-makers, the aggregation into a single value allowed the decision to provide support through a transparent assessment of alternatives (Edwards and Barron, 1994; Belton and Stewart, 2002; Leal-Junior and Guimarães, 2013).

MCDA applications available in the literature, commonly decisions are focused on alternatives that are relatively simple to identify (Montibeller and Franco, 2011). Moreover, at the strategic level, the decision-making process consists of a large number of alternatives, and often a finite set of criteria and viable alternatives conflict with the objectives (Hostmann et al., 2005; Montibeller and Franco, 2010).

Decisions of a higher complexity can be more successful if built upon knowledge shared by stakeholders with an assessment of all potential impacts (Keeney and Raiffa, 1993; Montibeller et al., 2006). Also according to Keeney (1996); Franco and Montibeller (2010), the decision-making process must meet the preferences and values of the different users and institutions, i.e., structuring and solving the problem must be constructed in conjunction with stakeholders. In the specific case of the Brazilian Navy, this solution could be through an assessment that considers all strategic-military characteristics (Brasil, 2004; 2007b).

For Wallenius et al. (2008) and Ensslin et al. (2010) an important consideration in the application of MCDA methods is the support for decision making in a broader sense. The MCDA aims to help the stakeholders think about the problem, as part of the construction of process. To Belton and Stewart (2002); Hostmann et al. (2005) also highlights the benefits of MCDA as it aids the decision-maker in learning about problems, their values and goals. The stakeholders and the organization can utilize MCDA in a problem-solving context in order to guide one toward the identifying of a preferred course of action.

According to Franco and Montibeller (2010), the main challenges in the MCDA methodology are the criteria to be considered in problematic situations and respective interactions. The multi-criteria approach is a decision support tool for diverse applications which can be exemplified as: the selection/supplier performance (Ho et al., 2010) or decision situations applied to climate change (Konidari and Mavrakis, 2007). There are different methods available in MCDA, for several approaches to the performance evaluation criteria and the elaboration of the ranking of the alternatives.

Already in the context of strategic decisions such as the location of a military base, Montibeller and Franco (2007; 2011) propose the application of MCDA through considerable interaction between decision-makers and the facilitator, who is a professional who helps to understand the process. As shown by Ensslin et al. (2010), if the strategic goals are established in a very general way, the multiple criteria can serve only to establish the choices of alternatives to the situation context.

The way of structuring the problem, according to the several authors (Durbach and Stewart, 2012; Montibeller and Franco, 2011), is such that decision-making should not be initiated by the definition of the alternatives. It is important for the organization to initially identify the main strategic objectives of the decision. This approach, also presented by Keeney (1996), reinforces the values of the organization and must be considered before listing the alternatives. Montibeller and Franco (2011) point out that a good choice necessarily needs to have a method and an elaborate theoretical foundation, in which all the implications and consequences of the results are identified.

\section{METHODOLOGY}

\subsection{Case study decision}

The problem of structuring, or the process of identifying the organization's values and criteria relevant to the context, begins by reviewing the literature and analysis of the unclassified normative documents of the Ministry of Defense and the Brazilian Navy. Subsequently, through interviews, criteria and sub-criteria were selected and evaluated. The interviews were individual, with a total of seven naval-officers (Lieutenant Commander, Commander, and Captain) from the Brazilian Navy, all in leading positions, but in different roles in naval administration.

For this case study, the MAVT (Belton and Stewart, 2002; Goodwin and Wright, 2004) and the Swing Weights approach (Montibeller and Franco, 2007; Gomes et al., 2011) were applied. In this decision the MAVT was used, as it provides a more rational basis for the construction of the strategic decision model for naval base selection. In other words, the MAVT is used as a means of organizing the collection of information related to the decision, such as the identification and evaluation of all criteria. The stakeholder's preferences were structured so as to represent the values and multiple objectives related to the naval base location problem.

Therefore, we built a decision making model consistent with the organization's values and preferences of the group of decision makers, without considering potential alternatives. These preferences were represented by the weights (constant scale) and value functions of the criteria, as presented below. Figure 1 shows the flowchart developed for the construction of the model as can be observed.

- Step 1: the problem was structured through the iden- 


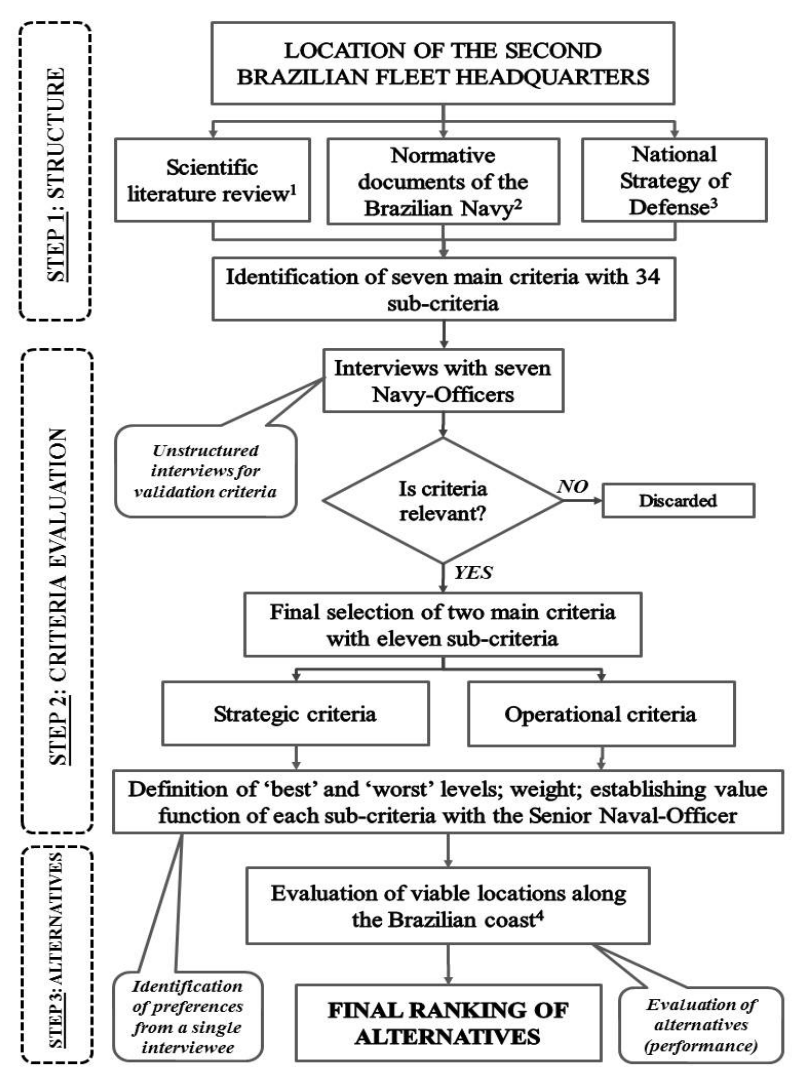

Figure 1: Flowchart of the decision model for naval base selection. [1]=literature review, Table A1 (appendix); [2]=(Brasil, 2003; 2004; 2006); [3]=(Brasil, 2008); [4]=(Brasil, 2009; 2012]

tification of criteria for scientific literature and the association of attributes and values through regulatory/normative documentation of the Brazilian Government.

- Step 2: seven interviews were conducted with naval-officers. The purpose of these interviews is to validate all values and criteria identified in the previous step. In other words, every 34 pre-selected criteria were evaluated and it was defined which would be incorporated into the decision model. These criteria were also classified into Operational or Strategic criteria. A set of measurable attributes for naval base selection were also established in this step. However the process of preference elicitation was accomplished only with the input from the highest ranking naval officer (more expertise), as will be demonstrated below. Thus, in this case study, we are not considering a group decision processes with all naval-officers interviewed, where there is a need for more complex modeling integration preferences.

- Step 3: the pay-offs resulting from the implementation of potential alternatives were evaluated. This performance evaluation is a tool to improve the understanding of preferences, in order to represent the actual values of the interviewed officers.

Importantly, due to the limitations of this study, it was not possible to apply the brainstorming techniques (group decision), as proposed in the standards of the Brazilian Navy (Brasil, 2006; 2007b). That is to say, a unified interaction with the group of stakeholders involved in this case study has not been possible. However, the criteria, sub-criteria and their weightings of the decision model were established, even without a group meeting.

\subsection{Criteria and preferences}

According to the interviewed officer's preferences, the criteria were divided into two main aspects. The first Strategic, built from the normative documents of the Ministry of Defense and the Brazilian Navy. The second aspect is Operational criteria identified from the literature review (Table 1). The complete definition of Strategic and Operation criteria are present in the Table A2 and A 3 of Appendix.

After identifying the set of criteria, it is necessary to construct the value hierarchical structure (Table 1). Montibeller and Franco $(2007 ; 2011)$ and Ensslin et al. (2010) propose a tool to improve the understanding of decision-making through the construction of impact levels and performance evaluations, which should represent local and global preferences of the decision maker. For Goodwin and Wright (2004) the preference of the users at different impact levels, or the performance quantification is called the value function. This function is a way of ordering the intensity of the preferences of the decision maker, the difference in attractiveness between potential actions. Through a range of values, the points that allow the adjustment of a value function representing the preferences are identified. This interaction with decision-makers is also known as elicitation. This process identifies the details of value functions, but can be demanding. However, according to Edwards and Barron (1994), the contribution of those important details or more valuable choices is often negligible.

The additive value function $V(a)$ was built from a comparison of the effects on each of the criteria. It can be determined by Equation 1 (Belton and Stewart, 2002; Gomes et al., 2011).

$$
V(a)=\sum_{i=1}^{m} w_{i} v_{i}(a)
$$

Where $v_{i}(a)$ is the value of each alternative on each criterion and $w_{i}$ is the criterion weights. The additive value function determines the total values of each alternative. So the recommended choice for the decision maker will be the alternative that gets the highest value. An important point is the additive value function (Equation 1) exists if and only if the attributes are mutually preferentially independent (for details, see Keeney, 1993).

In the construction process of the value function, as demonstrated by Montibeller and Franco (2007), one should identify the decision maker's preferences with the most desirable value to be considered 'best' (best feasible), where all needs are met in a given criterion. Subsequently, one should establish the minimum value that can be considered 'worst' (worst acceptable), i.e., poor performance, but it would still be acceptable for the users and which would remain a viable alternative. These impact levels 'best' and 'worst' are considered the anchor values for a range of functions from 0 to 100 . From the anchor values can be deter- 
mined the corresponding values of intermediate levels in the range of the function of each criterion.

The numerical scales of operational sub-criteria were identified from the reports from Brazil's National Agency for Waterway Transportation (Brasil, 2009; 2012) and subsequently validated and constructed in the interviews. Therefore, we identify the operational characteristics of each location, for example, the sub-criterion 'tide', and the senior decision maker indicated 'best', 'worst' levels and its value function. The MAVT also allows the construction of weights among the criteria by Swing Weights procedure (Goodwin and Wright, 2004; Montibeller et al., 2006; Gomes et al., 2011). This technique provides a numerical index associated with the preferences of the criteria, that is, a way of determining the order of importance of the attributes, also adopting a value scale of from 0 to 100 , the most important being the higher value. In other words, the scale values are determined for different criteria, identifying what is the preference for the decision maker and setting a value equivalent to the other, compared to the first. Then, we identify how the stakeholder is willing to lose (or replace) in a certain criterion and to gain in another. As a last step, once all values are scaled to all established criteria, the weighing of each attribute and their performance in each alternative is calculated as follows: (Figure 2).
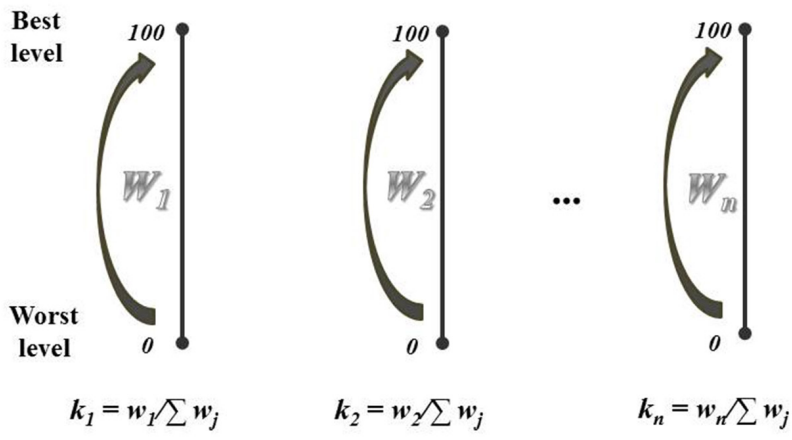

Figure 2: Elicitation outline by Swing Weights.

Table 1 presents the set of criteria, sub-criteria, levels of impact identified and their weights of the final decision model.

Table 1: Criteria, sub-criteria and their weight (bracketed) and levels of impacts for the naval base selection.

\begin{tabular}{|c|c|c|c|}
\hline Criteria & Sub-criteria 1 & Sub-criteria 2 & Impact levels \\
\hline \multirow{7}{*}{ 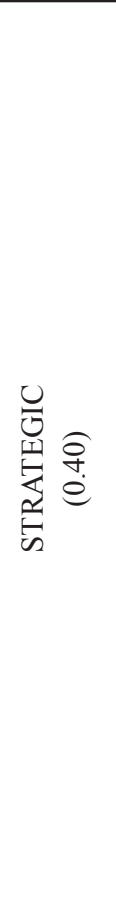 } & \multirow{2}{*}{$\begin{array}{l}\text { Dissuasion as a } \\
\text { result of sea denial } \\
\qquad(0.45)\end{array}$} & $\begin{array}{l}\text { Mouth of the Amazon River (distance) } \\
\qquad(0.75)\end{array}$ & $\begin{array}{c}\text { best: } 0 \mathrm{~km} \\
\text { worst: } 3,000 \mathrm{~km}\end{array}$ \\
\hline & & $\begin{array}{l}\text { Northern Maritime Border (distance to the northern limit of the } \\
\text { Brazilian jurisdictional waters) } \\
\qquad(0.25)\end{array}$ & $\begin{array}{c}\text { best: } 600 \mathrm{~km} \\
\text { worst: } 3,800 \mathrm{~km}\end{array}$ \\
\hline & \multirow{2}{*}{$\begin{array}{l}\text { Naval power } \\
\text { projection } \\
\quad(0.20)\end{array}$} & $\begin{array}{l}\text { Participation in the missions of UN responsibility (distance to } \\
\text { Caribbean region) } \\
\qquad(0.60)\end{array}$ & $\begin{array}{l}\text { best: } 4,000 \mathrm{~km} \\
\text { worst: } 8,000 \mathrm{~km}\end{array}$ \\
\hline & & $\begin{array}{l}\text { Participation in other international missions-African continent } \\
\text { (distance to the west coast of Africa) } \\
\qquad(0.40)\end{array}$ & $\begin{array}{l}\text { best: } 5,000 \mathrm{~km} \\
\text { worst: } 9,000 \mathrm{~km}\end{array}$ \\
\hline & \multirow{3}{*}{$\begin{array}{l}\text { Sea control } \\
\quad(0.35)\end{array}$} & $\begin{array}{l}\text { Defense of important economic infrastructure/facilities nearby } \\
\text { location (number) } \\
(0.50)\end{array}$ & $\begin{array}{l}\text { best: } 50 \\
\text { worst: } 1\end{array}$ \\
\hline & & $\begin{array}{l}\text { Maritime activities in commercial ports near location } \\
\text { (qualitative) } \\
(0.30)\end{array}$ & $\begin{array}{l}\text { best: high } \\
\text { worst: low }\end{array}$ \\
\hline & & $\begin{array}{l}\text { Defense of the state capitals (distance to the nearest capital) } \\
\qquad(0.20)\end{array}$ & $\begin{array}{c}\text { best: } 0 \mathrm{~km} \\
\text { worst: } 150 \mathrm{~km}\end{array}$ \\
\hline \multirow{4}{*}{ 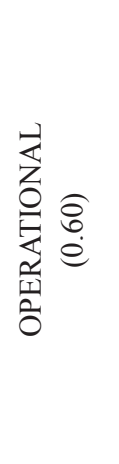 } & $\begin{array}{l}\text { Change of tide }(\mathrm{m}) \\
\qquad(0.25)\end{array}$ & - & $\begin{array}{c}\text { best: } 2 \mathrm{~m} \\
\text { worst: } 10 \mathrm{~m}\end{array}$ \\
\hline & $\begin{array}{l}\text { Channel depth }(\mathrm{m}) \\
\qquad(0.40)\end{array}$ & - & $\begin{array}{l}\text { best: } 25 \mathrm{~m} \\
\text { worst: } 9 \mathrm{~m}\end{array}$ \\
\hline & $\begin{array}{l}\text { Pre-existence of a small } \\
\text { naval base (yes/no) } \\
(0.10)\end{array}$ & - & $\begin{array}{l}\text { best: yes } \\
\text { worst: no }\end{array}$ \\
\hline & $\begin{array}{l}\text { Local infrastructure- } \\
\text { vicinity (qualitative) } \\
\qquad(0.25)\end{array}$ & - & $\begin{array}{l}\text { best: high } \\
\text { worst: low }\end{array}$ \\
\hline
\end{tabular}


The value function may be linear or not, depending upon the decision makers preference. In this case study, the functions were obtained by the bisection method (Goodwin and Wright, 2004; Montibeller and Franco, 2007). A senior naval-officer interviewed (highest hierarchy) indicates the corresponding value in the intermediate range of anchors levels.
The criteria that are used to determine the distance between the locations and Operational criteria 'tide', the value functions are linear, due to the preferences indicated by respondents. As for the other criteria, the value functions are presented in Tables 2 and 3.

Table 2: Value functions (nonlinear) for sub-criteria 'defense of important economic infrastructure/facilities' and 'channel depth'.

\begin{tabular}{lll}
\hline Value function scale & Defense infrastructure $\left(\boldsymbol{n}^{\boldsymbol{o}}\right)$ & Channel depth $(\boldsymbol{m})$ \\
\hline 100 (best) & 50 & 25 \\
75 & 28 & 14 \\
50 & 15 & 11 \\
25 & 6 & 10 \\
0 (worst) & 1 & 9 \\
\hline
\end{tabular}

Table 3: Value functions (qualitative) for sub-criteria 'maritime activities in commercial ports', 'pre-existence of a small naval base' and, 'local infrastructure'.

\begin{tabular}{llll}
\hline Value function scale & Maritime activities & Pre-existence of a naval base & Local infrastructure \\
\hline 100 (best) & high & yes & high \\
50 & medium & - & medium \\
0 (worst) & low & no & low \\
\hline
\end{tabular}

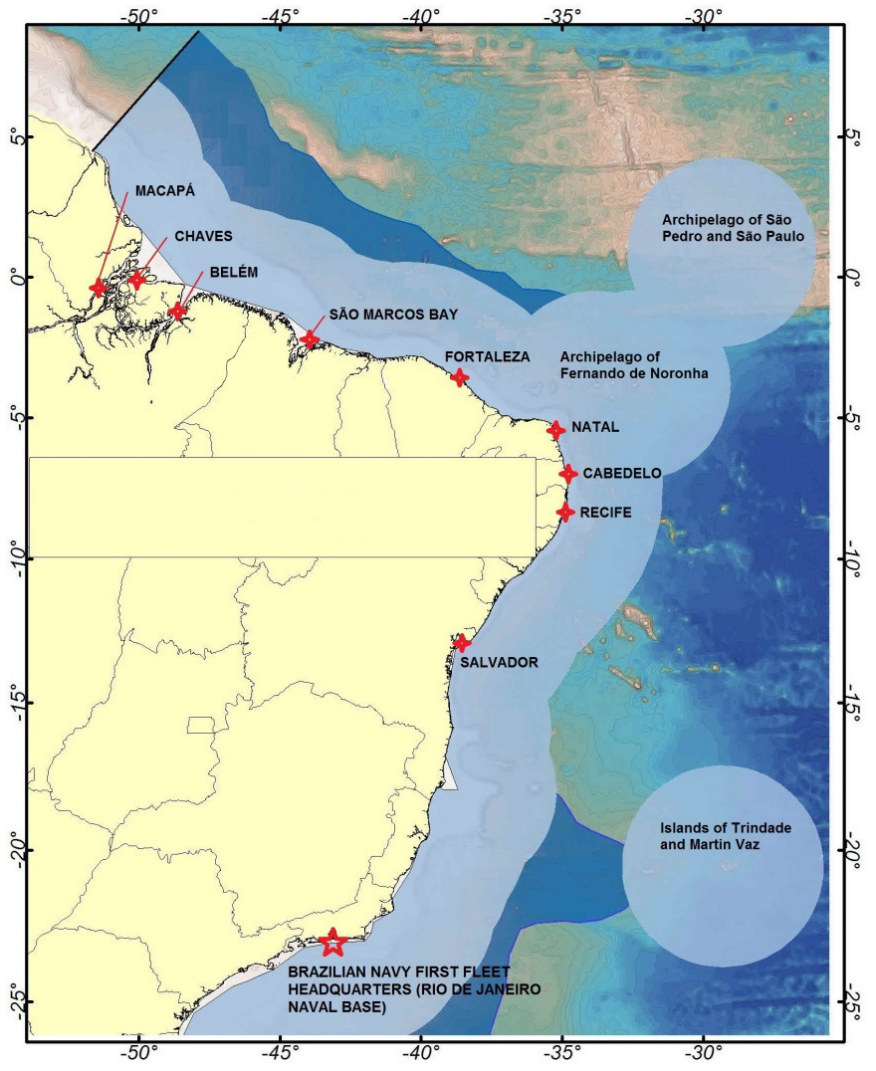

Figure 3: Map of Brazil with the pre-selected location and the current the First Brazilian Fleet Headquarters.(Adapted: https:// www.mar.mil.br/secirm/portugues/leplac.html).
The use of the value function and weight criteria provide the decision-maker with an easy to understand and apply procedure according to eliciting in MAVT, while both are concepts for multi-criteria aggregation (Belton and Stewart, 2002). It is important to mention that two criteria ('maritime activity' and 'local infrastructure') were constructed from a qualitative scale for the measurement of a direct quantitative indicator. Note: there was no consensus among interviewees in this elicitation.

\subsection{Pre-selection of alternatives}

For the selection of potential locations for a naval base, it is noteworthy to mention that along the northern and northeastern coast of Brazil there are many points that can meet certain attributes. However, in order to make a viable pre-selection and at the same time to limit the viable alternatives in this study, a common concept was used for the construction of infrastructure along the coast for the movement of large ships: a geographically sheltered area, such as a bay, estuary or river channel, and the availability of physical space for the buildings (Figure 3).

The values of all the criteria of pre-selected locations are presented in Tables 4 and 5, obtained through documentary research with their characteristics. 
Table 4: Pre-selected locations with the respective values of Strategic sub-criteria.

\begin{tabular}{llllllll}
\hline & \multicolumn{7}{c}{ Strategic (distance in $\mathbf{k m} /$ numbers in units) } \\
\cline { 2 - 7 } Locations & $\begin{array}{l}\text { Amazon } \\
\text { river }^{(A)}\end{array}$ & $\begin{array}{l}\text { Northern } \\
\text { border }\end{array}$ & Caribbean & African coast & $\begin{array}{l}\text { Facilities } \\
\text { number }\end{array}$ & $\begin{array}{l}\text { Marit. } \\
\text { activities }\end{array}$ & $\begin{array}{l}\text { Defense } \\
\text { capitals }^{(B)}\end{array}$ \\
\hline Macapá & 9 & 650 & 4,160 & 7,680 & 12 & medium & 0 \\
Chaves & 85 & 665 & 4,175 & 7,695 & 4 & low & 125 \\
Belém & 28 & 770 & 4,130 & 7,450 & 20 & high & 0 \\
São Marcos & 555 & 1,150 & 4,445 & 6,905 & 25 & medium & 5 \\
Fortaleza & 1,170 & 1,710 & 4,970 & 6,115 & 30 & high & 0 \\
Natal & 1,650 & 2,180 & 5,440 & 5,660 & 20 & medium & 0 \\
Cabedelo & 1,850 & 2,335 & 5,610 & 5,570 & 15 & medium & 12 \\
Recife & 1,950 & 2,440 & 5,715 & 5,520 & 40 & high & 35 \\
Salvador & 2,650 & 3,155 & 6,430 & 5,695 & 25 & high & 15 \\
\hline
\end{tabular}

(A)-shortest distance between the two rivers channel (north or south)/(B)-Nearest state capital

Table 5: Pre-selected locations with the respective values of Operational sub-criteria.

\begin{tabular}{|c|c|c|c|c|}
\hline \multirow[b]{2}{*}{ Locations } & \multicolumn{4}{|c|}{ Operational (value in meters) } \\
\hline & Tide & Channel depth & Pre-exist. & Infra. \\
\hline Macapá & 3 & 10 & no & medium \\
\hline Chaves & 6 & 11 & no & low \\
\hline Belém & 6 & 9 & yes & high \\
\hline São Marcos Bay & 8 & 23 & no & high \\
\hline Fortaleza & 4 & 11 & no & high \\
\hline Natal & 4 & 10 & yes & high \\
\hline Cabedelo & 4 & 11 & no & high \\
\hline Recife & 5 & 12 & no & high \\
\hline Salvador & 3 & 18 & yes & medium \\
\hline
\end{tabular}

Based upon the values for Strategic criteria (Table 4) and Operational criteria (Table 5), it was possible to establish scales of differences in attractions that meet the decision maker's preferences (Ensslin et al., 2010). As considered viable alternatives, in order to contribute to the possible elevation of the intensity levels in each of the criteria, reevaluating the weights criteria and the value function scale.

\section{RESULTS AND DISCUSSION}

As discussed before, in the MAVT approach, the alternatives are ranked in a value scale of from 0 to 100 . The results are shown in Table 6, where the positions of alternatives can be seen, just considering the Strategic and $O p$ erational criteria individually and also the value of the end result, taking all criteria into consideration (last column).

Table 6: Result of the alternatives for the location of the second Brazilian Fleet Headquarters considering Strategic and Operational criteria and all other criteria (final ranking).

\begin{tabular}{|c|c|c|c|c|c|c|}
\hline \multirow[b]{2}{*}{ Locations } & \multicolumn{2}{|c|}{ Strategic } & \multicolumn{2}{|c|}{ Operational } & \multicolumn{2}{|c|}{ Overall performance } \\
\hline & Value & Rank position & Value & Rank position & Value & Rank position \\
\hline São Marcos Bay & 75 & 3 & 70 & 2 & 72 & 1 \\
\hline Fortaleza & 73 & 4 & 62 & 5 & 66 & 2 \\
\hline Salvador & 46 & 9 & 78 & 1 & 65 & 3 \\
\hline Recife & 62 & 5 & 64 & 4 & 63 & 4 \\
\hline Belém & 87 & 1 & 47 & 7 & 63 & 5 \\
\hline Natal & 58 & 7 & 65 & 3 & 62 & 6 \\
\hline Macapá & 78 & 2 & 46 & 8 & 59 & 7 \\
\hline Cabedelo & 52 & 8 & 62 & 6 & 58 & 8 \\
\hline Chaves & 61 & 6 & 31 & 9 & 43 & 9 \\
\hline
\end{tabular}


For the location of a new development or the selection of new sites, the literature discusses different aspects, usually based on certain demands by users, customers or business attractions. In view of strategic decisions, the model is built in tandem with the stakeholder, given the values and strategies upon the organization. The decision in a military transport is essential because a naval base has an expected long-term operation, and it is an important means of defending the country.

Analyzing the results considering only the Strategic criterion, the best alternative is Belém (score of 87), this is almost two times higher than the last placed option (Salvador) which is the furthest from the mouth of the Amazon River. When evaluating only the Operational criteria, the best location would be Salvador (with a score of 78; 2.5 times higher than Chaves, which was ranked last). Salvador presents the best operating conditions for receiving large navy ships. Finally, the São Marcos Bay, in Maranhão State, proved to be the best option for installing the Second Brazilian Fleet Headquarters, primarily due to the operational characteristics of the region. In overall performance, São Marcos Bay got a score 1.6 times higher than the last placed location (Chaves) and almost 10\% higher than the second placed location (Fortaleza).

After the problem is structured by MAVT, enabling stakeholders to better understand the whole decision making process. Moreover, as presented in this paper, it is possible to identify the real stakeholders' preferences, based on the value functions and the criteria weights. Therefore, the sets of trade-offs gained in the decision-making process involves the Strategic and Operational consequences arising from the location of the naval base. For example, in the perception of interviewees regarding the pay-offs, although the Strategic criteria are important for a military choice, the Operational requirements are limiting the classification of alternatives. As pointed out by one naval-officer: "a great place from a strategic point of view is not always a great place in terms of operating conditions". This is extremely important for a large naval base to have the ability receive major ships, specifically the Aircraft Carrier A-12 "São Paulo", which is the largest ship in the Brazilian Fleet.

On the compensatory rationality of MAVT (Keeney and Raiffa, 1993), trade-off judgments are important so as to identify the alternative that maximizes the satisfaction of the stakeholder, based on the overall result (multi-criteria) potential solutions. For example, in the evaluation of the decision maker's preferences (Table 1), the criterion of greater weight is the Operational (0.6) and the 'channel depth' sub-criterion (0.4). Therefore, the criterion Operational 'channel depth' is $24 \%$ the final value for the model. Regarding the Strategic criterion of greater weight, the distance to the 'mouth of the Amazon River', represents $13.5 \%$ of decision model. That is, for the interviewers of the Brazilian Navy, it is acceptable a reduction in the Strategic attributes in order to have greater benefits in Operational attributes during the decision making process.

In examining the evaluation criteria by MAVT, quite often respondents demonstrated difficulties in consistently expressing and quantifying preferences, and often the interaction was limited by time factors leaving no possibility for a group meeting. However, despite the fact that the Navy's decision had already been made in 2009 (Brasil, 2013), also opting for São Marcos Bay, the MAVT's contribution to understanding the decision-making process was significant.

A Sensitivity Analysis was conducted so as to evaluate the possible effects of changing some parameters of the decision model, especially those of the weights, in order to verify the robustness of options. This analysis was performed for the two main criteria (Strategic, Operation$a l$ ), where it is possible to evaluate potential changes in the rankings, with the modification of the weights, i.e., the decision maker's preference between criteria (Figure 4).

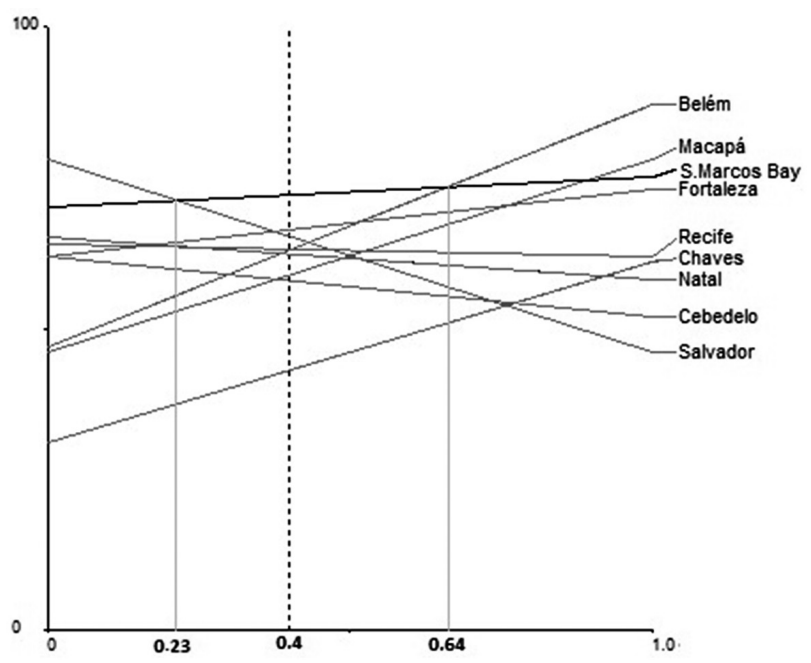

Figure 4: Ranking of the alternatives considering the variation of the weights between main criteria Strategic and Operational.

For Strategic criterion (Figure 4), which has the weight 0.4 , it can be observed that the São Marcos Bay alternative remains the best option from the minimum value of 0.23 , below which the best location would be Salvador. To change the preference criteria in the Strategic higher than 0.64 the Belém would be the best alternative location. In Operational criteria, weighing 0.6 to São Marcos Bay stands as the best option for values between 0.77 (max) and $0.36(\mathrm{~min})$, and from these extremes, the best alternative would be Salvador and Belém, respectively.

Therefore, even with a significant variation in preferences between the two main criteria, the São Marcos Bay remains the best alternative, showing that the result is robust and that fully meets the preferences established by group of Navy Officers interviewed. On the other hand, in a technical report by the Federal University of Pará, the navy's criteria are questioned (Brasil, 2010). According to this report, Chaves city was chosen as a suitable place for the new naval base. In this work, three technical criteria were evaluated: two for distance and one for channel depth, all being of the same weight. However, as can be seen in the results (Table 6), this location was last in the rankings because it only met the minimum requirements, but in comparison to the other alternatives, Chaves did not perform well in the total attributes considered.

Another way of looking to this Sensitivity Analysis is to construct the Pareto Frontier (Lu et al., 2011) and look for the non-dominated options. As show in Figure 5, where one can see that makes no sense in chose any alternative but Salvador, São Marcos Bay and Belém. In this fashion, the group of Navy Officers could be presented with these alter- 
natives and be told that any other alternative is "dominated" by these three ones, reducing, in this way, the following analysis work to be done by the decision maker.

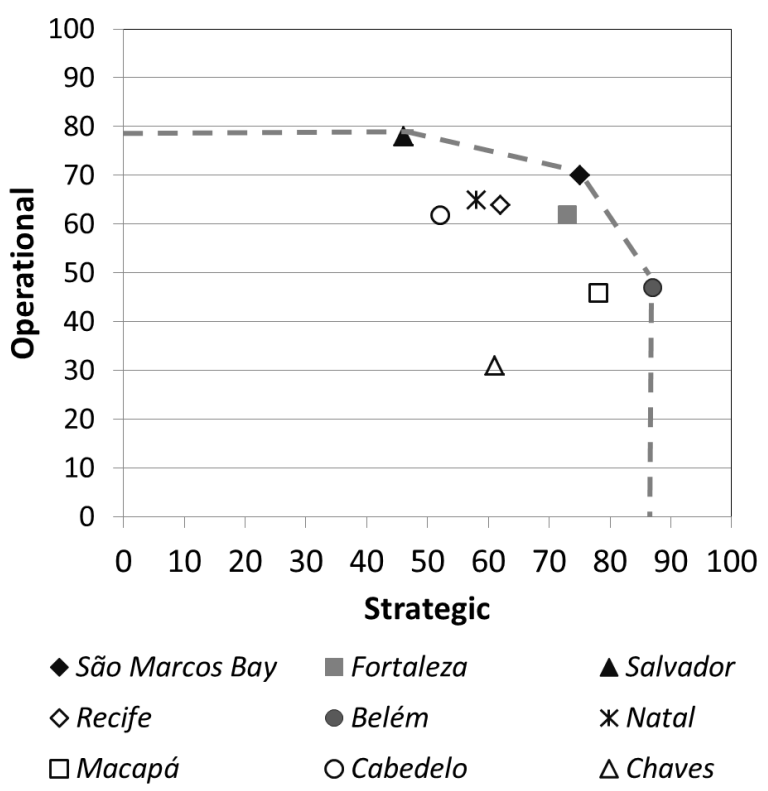

Figure 5: Pareto Frontier Analysis.

\section{CONCLUSION}

This paper proposed a framework in the process of strategic military decision to evaluate the key factors in maritime transport choice regarding the location of a naval base. The decision model applied in this case study supported the organization's values, and stimulated a systemic view in the identification and evaluation of criteria, in addition to the performance of the viable alternatives for the location of the Second Brazilian Fleet Headquarters.

In Section 2 we showed an overview of Brazil's National Strategy of Defense and identified the strategic criteria from the Brazilian Navy to transport decision. A literature review was analyzed to evaluate the technical criteria for commercial port selection and a total of thirty-four different sub-criteria were identified and divided into seven main categories of criteria. The methodology proposed was presented in Section 3. We developed the model with the Brazilian Navy's values and preferences from the interviewed military-officers. The framework was planned in three steps: problem structuring, criteria evaluation with MCDA approach and performance of alternatives. The results and discussion are presented in Section 4.

To evaluate the framework proposed we applied it in a real case study to describe the problems of selecting a naval base location. The case study was structured in order to meet the strategic values presented in normative documents of the Brazilian Government (National Strategy of Defense and the Doctrine of the Brazilian Navy), for aspects other than that of seaworthiness of ships. The proposed multi-criteria approach increases the decision-maker's confidence in analyzing the problem, since it helps to clarify his preferences and facilitates the understanding of the problem. A systemic view combined with a different approach was applied, for problem structuring, MCDA and analyzing the multiple value dimensions involved in the naval base selection problem.

According to the different views from the literature, it is possible to affirm that exist several approaches to solve this class of problems. However, the framework based on multi-criteria method also provides a conflict resolution on some criteria, since the value function analysis allows a consistent assessment of the minimum operating requirements for the movement of Navy ships. Moreover, in this case study there were two sub-criteria ('local infrastructure' and 'maritime activity') that were difficult to determine a numerical indicator, so a qualitative scale was applied due to a lack of consensus on a quantitative measure. Due to these two criteria, there was also difficulty in modeling the users' preferences as defined by MAVT. Although this type of scale is not appropriate because it allows some subjectivity among stakeholders, the decision model that was applied is transparent, in order that users and other stakeholders could accept the recommendations presented. On the other hand, this study has showed some evidence on the importance of operational criteria in the selection of a naval base, and it must be taken into consideration in the strategic-decision context as well. An important point: the development of this decision model is possible only if the Country previously defines its strategic long-term goals. For Brazil, these are shown in the NSD.

The framework proposed has shown to be suitable for the case of strategic military decisions and, independently, has also justified the choice defined by the Brazilian Navy in 2009. Furthermore, applying the model in a real case showed to be a completely appropriate and a reasonable option for future military decision-making problems. In this sense, we can say that the use of structured methods for choice is undoubtedly the best option for major government decisions, such as granting public infrastructure or the purchase of expensive equipment. However, it is important to note that the analysis of this study is limited due to the fact that this is a classified issue. Certain limitations occurred because there has been a wide range of discussions with the institutions involved and the need to make a more detailed survey in terms of infrastructure and operational requirements for the long term as well. Despite these limitations, we believe this study contributes to the knowledge advance in this area and provides important information for maritime transport and strategic decision-makers.

Finally, it is important to mention that, in respect to the armed forces in a civilian society, it should be noted that, as stated by the classic military strategist Carl von Clausewitz, a war is made by the armed forces, the government and the people (Proença-Junior and Duarte, 2005; Brasil, 2007). Therefore, a choice on the location of an important military base must be fully justified for the Brazilian population because ultimately it is the taxpayers who pay for the implementation of this project. 


\section{ACKNOWLEDGEMENTS}

This study has been supported by CNPq (grant $\mathrm{n}^{\mathrm{o}}$ 142212/2011-3) and CAPES Foundation (grant $\mathrm{n}^{\mathrm{o}}$ 14552/2013-2), as a PhD scholarship, and CNPq (grant $\mathrm{n}^{\circ}$ 311437/2013-3) as a Research Productivity Fellowship Level 2. We would like to thank three anonymous reviewers for comments and suggestions, which have helped us to improve the paper; the professors Gilberto Montibeller and Hugo Yoshizaki, for their contributions; and also all the Navy Officers interviewees for their availability and their help to our research. However, any opinions or conclusions in this article are those of the authors and do not necessarily reflect the views of the Brazilian Navy or Ministry of Defense.

\section{REFERENCES}

Aversa, R., Botter, R. C., Haralambides, H. E. e Yoshizaki, H. (2005) A Mixed Integer Programming Model on the Location of a Hub Port in the East Coast of South America. Maritime Economics \& Logistics, v. 7, n. 1, p. 1-18. DOI: 10.1057/ palgrave.mel.9100121

Belton, V. e Stewart, T. J. (2002) Multiple Criteria Decision Analysis: An Integrated Approach (1st ed.). Berlin: Springer. DOI: $10.1007 / 978-1-4615-1495-4$

Brasil (2003) Comando da Marinha. Manual de Logística da Marinha. Publicação EMA-400.

Brasil (2004) Comando da Marinha. Doutrina Básica da Marinha. Publicação EMA-305.

Brasil (2006) Comando da Marinha. Estudo de Estado-Maior. Publicação EMA-332.

Brasil (2007a) Comando da Marinha. Guia de Estudos de Estratégia. Publicação EGN-304B.

Brasil (2007b) Comando da Marinha. Processo de Tomada de Decisão. Publicação EGN-214.

Brasil (2008) Ministry of Defense. National Strategy of Defense. Disponível em: <http://www.defesa.gov.br/projetosweb/ estrategia/arquivos/estrategia_defesa_nacional_ingles.pdf $>$ Acesso em: 14 dez. 2015.

Brasil (2009) Agência Nacional de Transportes Aquaviários. Plano Geral de Outorgas. Disponível em: <http://www.antaq. gov.br/Portal/Portos_PGO.asp > Acesso em: 14 dez. 2015.

Brasil (2010) Universidade Federal do Pará. Projeto para Esquadra da Marinha - Subsídios técnicos.

Brasil (2012) Agência Nacional de Transportes Aquaviários. Principais Portos Brasileiros (dados técnicos). Disponível em: $<$ http://www.antaq.gov.br/Portal/Portos_PrincipaisPortos.asp> Acesso em: 14 dez. 2015.
Brasil (2013) Comando do Exército. Boletim do Exército 43/2013. Disponível em: <http://www.sgex.eb.mil.br/sistemas/ be/boletins.php> Acesso em: 14 dez. 2015.

Caruzzo, A., Trentim, M. H. e Belderrain, M. C. N. (2012) Previsão Meteorológica para as Comissões da Esquadra Brasileira: Considerações sobre a Gestão de Risco nas Operações Navais. Pesquisa Naval, v. 25, p. 32-41. DOI: 10.13140/2.1.3815.8084

Chang, Y.-T., Lee, S.-Y. e Tongzon, J. L. (2008) Port Selection Factors by Shipping Lines: Different Perspectives Between Trunk Liners and Feeder Service Providers. Mar Policy, v. 32, n. 6, p. 877-885. DOI: 10.1016/j.marpol.2008.01.003

Chou, C.-C. (2007) A Fuzzy MCDM Method for Solving Marine Transshipment Container Port Selection Problems. Applied Mathematics and Computation, v. 186, n. 1, p. 435-444. DOI: 10.1016/j.amc.2006.07.125

Comes, T., Hiete, M., Wijngaards, N. e Schultmann, F. (2011) Decision maps: A framework for multi-criteria decision support under severe uncertainty. Decision Support Systems, v. 52, n. 1, p. 108-118. DOI: 10.1016/j.dss.2011.05.008

Cruz, M. R. P. da, Ferreira, J. J. M. e Azevedo, S. G. (2013a) Key factors of seaport competitiveness based on the stakeholder perspective: An Analytic Hierarchy Process (AHP) model. Maritime Economics \& Logistics, v. 15, n. 4, p. 416-443. DOI: $10.1057 / \mathrm{mel} .2013 .14$

Cruz, M. R. P. da, Ferreira, J. J. M. e Azevedo, S. G. (2013b) Logistics resources in seaport performance: multi-criteria analysis. Maritime Policy \& Management, v. 40, n. 6, p. 588613. DOI: $10.1080 / 03088839.2013 .777979$

Durbach, I. N. e Stewart, T. J. (2012) Modeling uncertainty in multi-criteria decision analysis. European Journal of Operational Research, v. 223, n. 1, p. 1-14. DOI: 10.1016/j.ejor.2012.04.038

Edwards, W. e Barron, F. H. (1994) SMARTS and SMARTER: Improved Simple Methods for Multiattribute Utility Measurement. Organizational Behavior and Human Decision Processes, v. 60, n. 3, p. 306-325. DOI: 10.1006/obhd.1994.1087

Ensslin, L., Giffhorn, E., Ensslin, S. R., Petri, S. M. e Vianna, W. B. (2010) Avaliação do Desempenho de Empresas Terceirizadas com o Uso da Metodologia Multicritério de Apoio à Decisão Construtivista. Pesquisa Operacional, v. 30, n. 1, p. 125-152. DOI: $10.1590 / \mathrm{S} 0101-74382010000100007$

Farahani, R. Z., SteadieSeifi, M. e Asgari, N. (2010) Multiple Criteria Facility Location Problems: A Survey. Applied Mathematical Modelling, v. 34, n. 7, p. 1689-1709. DOI: 10.1016/j.apm.2009.10.005

Figueira, J.; Greco,S. e Ehrgott, M. (2005) Multiple Criteria Decision Analysis: State of Art Surveys. Boston: Springer, 2005.

Franco, L. A. e Montibeller, G. (2010) Problem Structuring for Multicriteria Decision Analysis Interventions. In: COCHRAN, J.J. (Ed.). Wiley Encyclopedia of Operations Research and Management Science. Wiley. DOI: 10.1002/9780470400531.eorms0683 
Gomes, L. F. A. M., Rangel, L. A. D. e Leal-Junior, M. da R. (2011) Treatment of uncertainty through the interval Smart/ Swing Weighting Method: a case study. Pesquisa Operacional, v. 31, n. 3, p. 467-485. DOI: 10.1590/S0101-74382011000300004

Goodwin, P. e Wright, G. (2004) Decision Analysis for Management Judgment (3 ed.). West Sussex: John Wiley \& Sons.

Guy, E. e Urli, B. (2006) Port Selection and Multicriteria Analysis: An Application to the Montreal-New York Alternative. Maritime Economics \& Logistics, v. 8, p. 169-186. DOI: 10.1057/palgrave.mel.9100152

Hicks, L. e Raney, C. (2003) The Social Impact of Military Growth in St. Mary's County, Maryland, 1940-1995. Armed Forces \& Society, v. 29, n. 3, p. 353-371. DOI: 10.1177/0095327X0302900303

Ho, W., Xu, X. e Dey, P. K. (2010) Multi-criteria Decision Making Approaches for Supplier Evaluation and Selection: A Literature Review. European Journal of Operational Research, v. 202, n. 1, p. 16-24. DOI: 10.1016/j.ejor.2009.05.009

Hostmann, M., Bernauer, T., Mosler, H.-J., Reichert, P. e Truffer, B. (2005) Multi-Attribute Value Theory as a Framework for Conflict Resolution in River Rehabilitation. Journal of MultiCriteria Decision Analysis, v. 13, n. 2-3, p. 91-102. DOI: 10.1002/mcda.375

Keeney, R. L. (1996) Value-focused Thinking: Identifying Decision Opportunities and Creating Alternatives. European Journal of Operational Research, v. 92, n. 3, p. 537-549. DOI: 10.1016/0377-2217(96)00004-5

Keeney, R. L. e Raiffa, H. (1993) Decisions with Multiple Objectives: Preferences and Value Trade-Offs (1ed.). New York: Cambridge University Press.

Kerr, C. I. V., Phaal, R. e Probert, D. R. (2014) Depicting the Future Strategic Plans of the Royal Australian Navy Using a Roadmapping Framework as a Visual Composite Canvas. Technology Analysis \& Strategic Management, v. 26, n. 1, p. 1-22. DOI: 10.1080/09537325.2013.843663

Konidari, P. e Mavrakis, D. (2007) A Multi-criteria Evaluation Method for Climate Change Mitigation Policy Instruments. Energy Policy, v. 35, p. 6235-6257. DOI: 10.1016/j.enpol.2007.07.007

Lama, J. S. L. e Dai, J. (2012) A Decision Support System for Port Selection. Transportation Planning and Technology, v. 35, n. 4, p. 509-524. DOI: 10.1080/03081060.2012.680822

Langen, P. (2004) Governance in Seaport Clusters. Maritime Economics \& Logistics, v. 6, p. 141-156. DOI: 10.1057/palgrave. mel.9100100

Leal-Junior, I. C. e Guimarães, V. A. (2013) Análise da Ecoeficência nas Operações de Terminais Portuários com a Aplicação de Técnica de Auxílio Multicritério à Decisão. Transportes, v. 21, n. 3, p. 40-47. DOI: 10.4237/transportes.v21i3.688
Lirn, T. C., Thanopoulou, H. A., Beynon, M. J. e Beresford, A. K. C. (2004) An Application of AHP on Transhipment Port Selection: A Global Perspective. Maritime Economics \& Logistics, v. 6, n. 1, p. 70-91. DOI: 10.1057/palgrave.mel.9100093

Lu, L., Anderson-Cook, C. M. e Robinson, T. J. (2011) Optimization of Designed Experiments Based on Multiple Criteria Utilizing a Pareto Frontier. Technometrics, v. 53, n. 4, p. 353-365. DOI: 10.1198/TECH.2011.10087

Madeira, A. G., Cardoso, M. M., Belderrain, M. C. N., Correia, A. R. e Schwanz, S. H. (2012) Multicriteria and Multivariate Analysis for Port Performance Evaluation. International Journal of Production Economics, v. 140, n. 1, p. 450-456. DOI: 10.1016/j.ijpe.2012.06.028

Magala, M. e Sammons, A. (2008) A New Approach to Port Choice Modelling. Maritime Economics \& Logistics, v. 10, n. 1-2, p. 9-34. DOI: 10.1057/palgrave.mel.9100189

Montibeller, G. e Franco, L. A. (2007) Decision and Risk Analysis for the Evaluation of Strategic Options. In F. A. O'Brien, R. G. Dyson (eds.), Supporting Strategy: Frameworks, Methods and Models (1 ed., pp. 251-284). Chichester: Wiley.

Montibeller, G. e Franco, L. A. (2010) Multi-Criteria Decision Analysis for Strategic Decision Making. In C. Zopounidis, P. M. Pardalos (eds.), Handbook of Multicriteria Analysis (1 ed., pp. 25-48). Berlin: Springer. DOI: 10.1007/978-3-540-92828-7_2

Montibeller, G. e Franco, L. A. (2011) Raising the Bar: Strategic Multi-criteria Decision Analysis. Journal of the Operational Research Society, v. 62, n. 5, p. 855-867. DOI: 10.1057/ jors. 2009.178

Montibeller, G., Gummer, H. e Tumidei, D. (2006) Combining Scenario Planning and Multi-Criteria Decision Analysis in Practice. Journal of Multi-Criteria Decision Analysis, v. 14, p. 5-20. DOI: $10.1002 /$ mcda.403

Murphy, P. R. e Daley, J. M. (1994) A Comparative Analysis of Port Selection Factors. Transportation Journal, v. 34, n. 1, p. 15-21.

Notteboom, T. (2011) An Application of Multi-criteria Analysis to the Location of a Container HUB Port in South Africa. Maritime Policy \& Management, v. 38, n. 1, p. 51-79. DOI: $10.1080 / 03088839.2010 .533710$

Onut, S., Tuzkaya, U. R. e Torun, E. (2011) Selecting Container Port Via a Fuzzy ANP-based Approach: A Case Study in the Marmara Region, Turkey. Transport Policy, v. 18, n. 1, p. 182 193. DOI: $10.1016 /$ j.tranpol.2010.08.001

Paloyo, A. R., Vance, C. B. e Vorell, M. C. (2010) The Regional Economic Effects of Military Base Realignments and Closures in Germany. Defence and Peace Economics, v. 21, n. 5, p. 567-579. DOI: $10.1080 / 10242694.2010 .524778$

Proença-Junior, D. e Duarte, E. E. (2005) The Concept of Logistics Derived from Clausewitz: All that is Required so that the Fighting Force Can Be Taken as a Given. Journal of Strategic Studies, v. 28, n. 4, p. 645-677. DOI: 10.1080/01402390500301046 
Tran, N. K. (2011) Studying Port Selection on Liner Routes: An Approach From Logistics Perspective. Research in Transportation Economics, v. 32, n. 1, p. 39-53. DOI: 10.1016/j. retrec.2011.06.005

Ugboma, C., Ugboma, O. e Ogwude, I. C. (2006) An Analytic Hierarchy Process (AHP) Approach to Port Selection Decisions Empirical Evidence from Nigerian Ports. Maritime Economics \& Logistics, v. 8, 251-266. DOI: 10.1057/palgrave.mel.9100160

USA. (2010) Department of the Navy. Naval Operations Concept 2010. Washington. Disponível em: <http://www.navy.mil/ maritime/noc/NOC2010.pdf\$ Acesso em: 14 de dez. 2015.

Wallenius, J., Dyer, J. S., Fishburn, P. C., Steuer, R. E., Zionts, S. e Deb, K. (2008) Multiple Criteria Decision Making, Multiattribute Utility Theory: Recent Accomplishments and What Lies Ahead. Management Science, v. 54, n. 7, p. 13361349. DOI: $10.1287 / \mathrm{mnsc} .1070 .0838$ 
APPENDIX - STRATEGIC DECISIONS IN TRANSPORT:

A CASE STUDY FOR A NAVAL BASE SELECTION IN BRAZIL

Table A1: Summary of approaches and criteria for port selection.

\begin{tabular}{|c|c|c|c|}
\hline Context & Approaches & Main criteria and (n of sub-criteria) & Reference \\
\hline $\begin{array}{l}\text { Criteria comparison for } \\
\text { commercial port selection }\end{array}$ & $\begin{array}{l}\text { Questionnaires } \\
\text { ( } 5 \text { classification levels) }\end{array}$ & $\begin{array}{l}\text { - infrastructure/operational (20) } \\
\text { - service level (3) } \\
\text { - cargo capacity (4) }\end{array}$ & $\begin{array}{l}\text { Murphy; } \\
\text { Daley, } 1994\end{array}$ \\
\hline Commercial port selection & Delphi + AHP & $\begin{array}{l}\text { - infrastructure/operational (3) } \\
\text { - service level/port management (3) } \\
\text { - geographical location (3) } \\
\text { - cost (3) }\end{array}$ & $\begin{array}{l}\text { Lirn et al., } \\
2004\end{array}$ \\
\hline HUB port selection & Linear Programming & $\begin{array}{l}- \text { income }(1) \\
-\operatorname{cost}(1)\end{array}$ & $\begin{array}{l}\text { Aversa et al., } \\
2005\end{array}$ \\
\hline $\begin{array}{l}\text { Commercial ports evaluation } \\
\text { between two cities }\end{array}$ & AHP & $\begin{array}{l}\text { - infrastructure/operational (5) } \\
\text { - service level (1) } \\
\text { - geographical location (3) }\end{array}$ & $\begin{array}{l}\text { Guy; Urli, } \\
2006\end{array}$ \\
\hline $\begin{array}{l}\text { Commercial port selection in } \\
\text { Nigeria }\end{array}$ & AHP & $\begin{array}{l}\text { - infrastructure/operational (1) } \\
\text { - service level/efficiency (1) } \\
\text { - geographical location (1) } \\
\text { - cost (1) } \\
\text { - frequency of ship (1) } \\
\text { - reputation (1) } \\
\text { - user service (1) }\end{array}$ & $\begin{array}{l}\text { Ugboma et } \\
\text { al., } 2006\end{array}$ \\
\hline HUB port selection & Fuzzy + multi-criteria & $\begin{array}{l}\text { - infrastructure/operational (3) } \\
\text { - service level/efficiency (4) } \\
\text { - geographical location (3) } \\
\text { - cargo capacity (3) } \\
\text { - cost (2) } \\
\text { - other criteria (3) }\end{array}$ & Chou, 2007 \\
\hline $\begin{array}{l}\text { Commercial port evaluation } \\
\text { for shipping companies }\end{array}$ & $\begin{array}{l}\text { Questionnaires } \\
\text { (5 classification levels) }\end{array}$ & $\begin{array}{l}\text { - infrastructure/operational (5) } \\
\text { - service level (4) } \\
\text { - geographical location (2) } \\
\text { - cargo capacity (5) } \\
\text { - reputation (4) } \\
\text { - user service (1) }\end{array}$ & $\begin{array}{l}\text { Chang et al., } \\
2008\end{array}$ \\
\hline $\begin{array}{l}\text { Naval base selection for the } \\
\text { Brazilian fleet }\end{array}$ & Multi-criteria & $\begin{array}{l}\text { - distance priority area defense (1) } \\
\text { - distance from cities (1) } \\
\text { - distance of 50m isobaths/restricting maritime access (1) }\end{array}$ & Brasil, 2010 \\
\hline $\begin{array}{l}\text { Location of a container HUB } \\
\text { port in South Africa }\end{array}$ & SWOT analysis + AHP & $\begin{array}{l}\text { - infrastructure/operational (10) } \\
\text { - service level/efficiency (7) } \\
\text { - geographical location (2) } \\
\text { - cargo capacity (4) } \\
\text { - cost (2) } \\
\text { - reputation (2) } \\
\text { - user service (4) }\end{array}$ & $\begin{array}{l}\text { Notteboom, } \\
2011\end{array}$ \\
\hline $\begin{array}{l}\text { Selecting container port in } \\
\text { Turkey }\end{array}$ & Fuzzy + ANP & $\begin{array}{l}\text { - infrastructure/operational (3) } \\
\text { - service level/efficiency (3) } \\
\text { - geographical location (3) } \\
\text { - cargo capacity (3) } \\
\text { - cost (2) } \\
\text { - other criteria (3) }\end{array}$ & $\begin{array}{l}\text { Onut et al., } \\
2011\end{array}$ \\
\hline $\begin{array}{l}\text { Commercial port selection by } \\
\text { shipping routes }\end{array}$ & Linear Programming & $-\operatorname{cost}(1)$ & Tran, 2011 \\
\hline $\begin{array}{l}\text { DSS for a commercial port } \\
\text { selecting }\end{array}$ & AHP & $\begin{array}{l}\text { - infrastructure/operational (2) } \\
\text { - geographical location (1) } \\
\text { - cargo capacity (2) } \\
\text { - cost (1) }\end{array}$ & $\begin{array}{l}\text { Lama; Dai, } \\
2012\end{array}$ \\
\hline Port performance evaluation & $\begin{array}{l}\text { MCDA + multivariate } \\
\text { analysis }\end{array}$ & $\begin{array}{l}\text { - operational (2) } \\
\text { - service level/efficiency (5) } \\
\text { - cargo capacity (2) }\end{array}$ & $\begin{array}{l}\text { Madeira et } \\
\text { al., } 2012\end{array}$ \\
\hline Seaport competitiveness & Delphi + AHP & $\begin{array}{l}\text { - infrastructure/operational (3) } \\
\text { - geographical location (3) } \\
\text { - service level/port management (3) } \\
\text { - cost (3) }\end{array}$ & $\begin{array}{l}\text { Cruz et al., } \\
2013 \mathrm{a}\end{array}$ \\
\hline Seaport performance & $\mathrm{MCDA}+\mathrm{PCA}$ & $\begin{array}{l}\text { - operational (6) } \\
\text { - cargo capacity/service (6) }\end{array}$ & $\begin{array}{l}\text { Cruz et al., } \\
2013 b\end{array}$ \\
\hline
\end{tabular}


Table A2: Strategic criteria definition according the NSD and normative documents of Brazilian Navy (Brasil, 2003; 2004; 2006) and validated by the interviewees.

\begin{tabular}{ll}
\hline Strategic Criteria & Definition \\
\hline $\begin{array}{l}\text { Dissuasion as a result of } \\
\text { sea denial to the enemy } \\
\text { approaching Brazil }\end{array}$ & $\begin{array}{l}\text { The ability to defend a country's own sovereignty and prevent hostile naval forces from } \\
\text { approaching the Brazilian coast. For a Brazilian fleet, it is to protect the mouth of the } \\
\text { Amazon River and the sea borders in the Central Atlantic. Currently this is the region that } \\
\text { does not maintain a large naval base. }\end{array}$ \\
\hline Naval power projection & $\begin{array}{l}\text { The capacity to participate in peacekeeping or humanitarian missions under the } \\
\text { responsibility of the United Nations or friendly country. Currently the BN maintains } \\
\text { international operations in the Caribbean region, the African continent and the }\end{array}$ \\
Mediterranean Sea.
\end{tabular}

Table A3: Operational criteria definition selected by the literature review (Table A1) and validated by the interviewees.

\begin{tabular}{ll}
\hline Operation Criteria & Definition \\
\hline Change of Tide & $\begin{array}{l}\text { There is a need to tailor the structure of the Naval Base for large daily variations in sea } \\
\text { level. }\end{array}$ \\
\hline Channel depth & $\begin{array}{l}\text { The channel depth for the operation of large ships in the Brazilian fleet, in particular, } \\
\text { Aircraft Carriers. }\end{array}$ \\
\hline $\begin{array}{l}\text { Pre-existence of a small } \\
\text { naval base }\end{array}$ & $\begin{array}{l}\text { If the some localities along the Brazilian coast, there are already naval bases, so small that } \\
\text { they are unable to receive several vessels simultaneously. However, the pre-existence of a } \\
\text { base is an advantageous circumstance, since there is already infrastructure support. }\end{array}$ \\
\hline $\begin{array}{l}\text { Local infrastructure } \\
\text { (vicinity) }\end{array}$ & $\begin{array}{l}\text { The fact that there is a good infrastructure nearby or large cities, where it is possible to have } \\
\text { access to basic services for future workers, such as schools, hospitals, places of relaxation } \\
\text { etc. This attribute was considered by interviewees as an important criterion for selection. }\end{array}$ \\
\hline
\end{tabular}

